\title{
Partisipasi Anggota dan Pemanfaatan Instagram dalam Interaksi Komunitas Brand Ria Miranda
}

\author{
Satya Herlina Armananti, Donna Asteria \\ Universitas Indonesia \\ J1. Salemba Raya No. 4, Jakarta Pusat \\ satya.herlina@gmail.com,donnaasteria@gmail.com
}

Masuk tanggal : 30-08-2019, revisi tanggal : 25-10-2019, diterima untuk diterbitkan tanggal : 11-11-2019

\begin{abstract}
Communities can be formed from groups of people who have the same passion. In the life of modern society, the definition of community has developed so that it can form a brand community, which is a community of people with an interest in the same brand. Ria Miranda Loyal Customer (RMLC) is brand community of Ria Miranda. Community members scattered throughout the territory of Indonesia caused this community divided according to their respective regions. Geographically separated does not cause the strength of this community inferior to other communities. In every community the brand community is no exception, every member has needs that can be met through their participation in the community. Members in the brand community interact to fulfill needs and develop relationships between members. A strong community is a community that can unite a variety of individuals and can meet each other's needs and on the other hand can meet the needs of other individuals. This study aims to see how the participation of RMLC community members and the use of Instagram as a social media that supports community interaction. The results showed that interaction in the community occurred through the participation of community members consisting of member-to-member interactions and member-activity involvement. This is demonstrated through interpersonal communication done between members of the community and the involvement of members in activities organized by the community. Participation in interacting with each member can foster stronger ties between community members. Instagram plays an important role as a social media that members use to meet their needs in terms of sharing information related to brand products and references on product use. Likes and comments as an Instagram feature help build closer relationships between community members.
\end{abstract}

Keywords: brand community, Instagram, interaction, participation

\begin{abstract}
Abstrak
Komunitas dapat terbentuk dari sekelompok orang yang memiliki kegemaran yang sama. Dalam kehidupan masyarakat modern, definisi komunitas mengalami perkembangan sehingga dapat terbentuk sebuah brand community, yang merupakan komunitas sekelompok orang dengan minat pada sebuah brand yang sama. Ria Miranda Loyal Customer (RMLC) merupakan komunitas penggemar brand Ria Miranda. Anggota komunitas yang tersebar di seluruh wilayah Indonesia menyebabkan komunitas RMLC dibagi menurut wilayah masing-masing. Terpisahkan secara geografis tidak menyebabkan kekuatan komunitas ini kalah dengan komunitas lainnya. Dalam setiap komunitas tak terkecuali brand community, setiap anggota memiliki kebutuhan yang dapat dipenuhi lewat keikutsertaannya dalam komunitas. Anggota-anggota dalam brand community melakukan
\end{abstract}


interaksi untuk pemenuhan kebutuhan dan pengembangan hubungan antar sesama anggota. Komunitas yang kuat adalah komunitas yang dapat menyatukan beragam individu dan dapat memenuhi kebutuhan masing masing dan di sisi lain dapat memenuhi kebutuhan individu lainnya. Penelitian ini bertujuan untuk melihat bagaimana partisipasi anggota komunitas RMLC dan penggunaan Instagram sebagai media sosial yang menunjang interaksi komunitas. Hasil penelitian menunjukkan bahwa interaksi dalam komunitas terjadi melalui partisipasi anggota komunitas yang terdiri dari member-to-member interactions dan member-activity involvement. Hal ini ditunjukkan melalui komunikasi yang dilakukan secara interpersonal antar anggota komunitas satu sama lain serta keterlibatan anggota dalam kegiatan yang diselenggarakan komunitas. Partisipasi dalam berinteraksi yang dilakukan masing-masing anggota dapat menumbuhkan ikatan yang lebih kuat antar anggota komunitas. Instagram berperan penting sebagai media sosial yang digunakan para anggota untuk memenuhi kebutuhan mereka dalam hal berbagi informasi terkait produk brand dan referensi penggunaan produk. Likes dan comment sebagai fitur Instagram membantu membangun hubungan yang semakin akrab antar anggota komunitas.

Kata Kunci: Instagram, interaksi, komunitas brand, partisipasi

\section{Pendahuluan}

Komunitas terbentuk dari interaksi yang terjadi antar individu. Interaksi tersebut tidak bisa dihindarkan dari kodrat manusia sebagai makhluk sosial yang tidak dapat hidup sendiri. Muniz dan O'Guinn mengungkapkan manusia sebagai makhluk sosial, menemukan dan menciptakan komunitas yang mereka mau. Terkadang, mereka akan menemukannya di sekitar barang bermerek (DePaul University, 2007). Sebuah komunitas dapat terbentuk karena memiliki rasa ketertarikan yang sama akan suatu hal. Individu-individu yang tertarik akan satu brand (merek) yang sama akan merasa terhubung satu sama lain dan cenderung ingin membentuk ikatan yang lebih kuat.

Ketertarikan individu-individu dalam komunitas terhadap brand tertentu pada dasarnya berkaitan dengan budaya konsumen yang mereka alami. Budaya konsumen ini mencakup pola konsumsi terhadap barang-barang untuk mendukung gaya hidup mereka. Budaya ini biasanya melekat pada masyarakat khususnya dalam masyarakat modern. Mereka adalah masyarakat yang rentan terpaan iklan dari produsen dan menjadi sasaran konsumen barang-barang bermerek. Munculnya budaya konsumen adalah dimana barang-barang bermerek menggantikan komoditas, iklan menggantikan penjualan pribadi, dan konsumen individu menggantikan penduduk komunal (Muniz \& O’Guinn, 2001).

Pola konsumsi terhadap brand menjadi elemen penting dari terbentuknya sebuah brand community. Muniz dan O'Guinn (2001) juga berpendapat bahwa konsumsi terhadap brand merupakan landasan yang kuat dalam membentuk ikatan antar anggota komunitas. Dengan mengonsumsi brand secara berkesinambungan membuat mereka mengidentifikasikan diri mereka sebagai konsumen yang loyal. Hal ini juga dapat membuat konsumen merasa menjadi bagian dari komunitas.

Menjadi anggota dari brand community menunjukkan sikap dan niat positif terhadap brand yang diminati. Dari sisi konsumen sebagai anggota komunitas, ia mendapatkan nilai dari adanya praktik dan interaksi yang terjadi antar sesama anggota. McMillan dan Chavis (1986) menjelaskan dalam sebuah komunitas 
Satya Herlina Armananti, Donna Asteria: Partisipasi Anggota dan Pemanfaatan Instagram dalam Interaksi Komunitas Brand Ria Miranda

anggota komunitas dapat merasakan adanya rasa kebersamaan, perasaan yang menunjukkan kehadiran anggota lain dirasa penting, dan sebuah keyakinan dimana kebutuhan setiap anggota dapat tercapai dengan komitmen yang dibuat. Nilai-nilai yang dirasakan oleh anggota komunitas baik dari interaksi dengan anggota yang lain maupun dengan brand itu sendiri menumbuhkan ikatan yang lebih kuat dalam brand community.

Ria Miranda Loyal Customer (RMLC) atau komunitas brand Ria Miranda merupakan komunitas penggemar brand dari modest fashion bernama Ria Miranda. Ini merupakan contoh dari komunitas yang terbentuk karena para anggotanya memiliki ketertarikan yang sama terhadap brand Ria Miranda. Para anggota komunitas tidak hanya berasal dari satu wilayah saja, namun berada hampir di seluruh Indonesia. Keanggotaan mereka tidak terikat secara geografis, namun lebih terikat secara emosional.

Komunitas brand Ria Miranda dapat dikatakan sebagai komunitas dari brand modest atau moslem fashion terbesar di Indonesia. Dibandingkan brand lain yang merupakan kompetitor Ria Miranda, belum ada yang memiliki konsumen loyal sebesar RMLC. Sebagai brand yang masih relatif baru, ini merupakan pencapaian yang luar biasa bagi Ria Miranda. Dukungan dari para anggota komunitas memberikan sumbangsih besar bagi brand ini.

Anggota komunitas brand Ria Miranda mengidentifikasikan diri mereka sebagai konsumen yang loyal terhadap Ria Miranda dibandingkan terhadap brand lain. Hal ini dapat dilihat dari unggahan foto-foto di akun Instagram para anggota komunitas. Mereka kerap menunjukkan gaya berpakaian mereka mengenakan produk Ria Miranda serta membagikannya ke anggota komunitas yang lain. Sesungguhnya hal ini juga menunjukkan pola konsumsi mereka terhadap brand Ria Miranda.

Menariknya dari komunitas brand ini, para anggota komunitas terlihat memiliki ikatan yang kuat sebagai penggemar brand Ria Miranda. Ini dapat terlihat dari beberapa hal. Pertama, mereka memiliki perasaan yang dalam terhadap anggota komunitas yang lain. Seperti diungkapkan akun @ hetiww yang merupakan salah satu anggota RMLC.

"RMTS ituuuu semacam reuni tahunan yang selaluuu kami tunggutunggu. Ada perasaan yang mungkin ga semua orang bisa ngerti, kenapa segitunya event ini dinanti sama RMLC. Ada rasa rindu dan kekeluargaan di sana. Bertemu ratusan sahabat dari berbagai daerah dan profesi yang sama-sama membawa energi positif, saling support, dan saling mendoakan. Masha Allah. Ga terpikir dengan logika memang, begitu hebatnya selembar kain bisa membuat ikatan silaturahmi yang begitu indahnya. Semua ini karena sosok positif yang selalu menginspirasi. Yang seolah memberi pesan bahwa segala yang dikerjakan dari hati, akan sampai juga ke hati. Makasih banyak uni @ riamiranda sudah mempertemukan kami, yang tadinya hanya bisa sapa-sapaan melalui sosmed, jd bisa cupika-cupiki dan peluk2 erat" (Instagram, 2019) 
Hal serupa juga diungkapkan akun @ayuparamita berikut ini, "Alhamdulillahmelalui uni@riamiranda saya bisa dipertemukan dengan semua teman-teman cantik dan solehah di foto ini. Semoga silaturahmi kita selalu dijaga sama Allah. Terimakasih yah uni ria sudah mempertemukan kami semua” (Instagram, 2019)

Kedua, para anggotanya memiliki komitmen yang kuat dalam mendukung brand ini seperti dengan memberikan dukungan kepada Ria Miranda tiap menggelar fashion show. Ketiga, anggotanya sering menunjukkan kekompakan mereka seperti senang memakai baju yang sama dari brand Ria Miranda ketika sedang berkumpul bersama.

Karena komunitas Ria Miranda memiliki skala yang besar dan lingkup yang cukup luas, dalam berinteraksi anggota komunitas tidak saja secara offline namun juga online. Para anggota memanfaatkan media digital untuk memudahkan komunikasi dengan sesama anggota komunitas. Sebagai komunitas yang berbasis fashion, kebutuhan mereka akan informasi mengenai gaya berpakaian atau mode terkini dari Ria Miranda menjadi hal yang utama. Untuk memenuhi kebutuhan tersebut, anggota komunitas memanfaatkan media sosial Instagram sebagai wadah untuk berbagi konten fashion.

Keutamaan Instagram dalam hal visual sangat mendukung anggota komunitas dalam membagikan foto-foto fashion Ria Miranda kepada anggota komunitas yang lain. Selain itu, menurut data dari hootsuite WeAreSocial, Instagram termasuk dalam tiga media sosial yang paling banyak digunakan di Indonesia. Dalam hal ini, Instagram berperan penting sebagai media sosial yang dapat membuat anggota komunitas brand Ria Miranda dapat dilihat oleh orangorang di luar komunitas. Ini membantu anggota komunitas untuk mengidentifikasikan diri mereka secara sosial sebagai bagian dari anggota komunitas.

Interaksi yang dilakukan antar anggota komunitas Ria Miranda baik secara offline maupun online diasumsikan mampu menumbuhkan kohesivitas dari anggota komunitas. Hal ini juga tidak lepas dari partisipasi aktif dari masing-masing anggota komunitas. Partisipasi disini berarti anggota komunitas berkomunikasi dan terlibat secara aktif dalam kegiatan komunitas. Kegiatan komunitas yang terpusat pada brand dapat mendorong integrasi dan peluang pertumbuhan komunitas yang lebih lanjut bahkan jika partisipasi dilakukan tidak terikat secara geografis (Tsai et al., 2012).

Berdasarkan pemaparan diatas, penelitian ini memfokuskan pada interaksi anggota komunitas dalam membangun ikatan yang kuat sebagai sebuah komunitas brand. Maka dari itu, pertanyaan penelitiannya adalah bagaimana partisipasi anggota komunitas dalam berinteraksi dan bagaimana pemanfaatan Instagram sebagai media sosial untuk berinteraksi. Berdasarkan pertanyaan penelitian tersebut, maka tujuan dari penelitian ini yang pertama ialah untuk memahami partisipasi anggota dalam membangun interaksi dalam komunitas brand Ria Miranda, dan yang kedua untuk memahami pemanfaatan Instagram sebagai media untuk berinteraksi antar anggota komunitas. 
Satya Herlina Armananti, Donna Asteria: Partisipasi Anggota dan Pemanfaatan Instagram dalam Interaksi Komunitas Brand Ria Miranda

Penelitian ini diharapkan dapat memberikan manfaat bagi pembacanya, baik secara teoretis dan praktis. Secara teoritis, penelitian ini dilakukan untuk mengembangkan dan mengimplementasi konsep mengenai brand community dan interaksi dalam komunitas, dikaitkan dengan media sosial Instagram. Sedangkan secara praktis, penelitian ini berguna bagi perusahaan untuk mengetahui hubungan sosial yang terjadi dalam sebuah brand community sehingga dapat menjadi dasar bagi perusahaan untuk mengembangkan hubungan dengan komunitas.

\section{Metode Penelitian}

Penelitian ini menggunakan pendekatan kualitatif, pendekatan ini memiliki keunggulan memungkinkan orang untuk mengungkapkan apa yang benar-benar penting bagi mereka dengan kata-kata mereka sendiri (Beirao \& Cabral, 2007). Melalui pendekatan kualitatif, peneliti ingin lebih memahami bagaimana interaksi antar anggota komunitas untuk membangun ikatan dalam komunitas brand Ria Miranda.

Strategi penelitian yang dipilih yaitu konstruktivis yang merujuk pada penciptaan makna individual atas pengetahuan relatif terhadap konteks sosial (Fraser et al., 2012). Strategi ini berusaha menjelaskan bagaimana sekelompok orang mengonstruksikan realitas yang dipercaya, diyakini, dan dipahami. Menurut Patton (1987), para peneliti konstruktivis mempelajari beragam realitas yang terkonstruksi oleh individu serta implikasi dari konstruksi tersebut bagi kehidupan mereka dengan yang lain. Disini peneliti berusaha memahami bagaimana informan berdasarkan pengalamannya sebagai anggota komunitas RMLC mengkonstruksikan interaksi yang terjadi dalam komunitas melalui partisipasi atau keterlibatannya dalam interaksi tersebut, serta melalui pemanfaatan media sosial Instagram.

Untuk metode pengumpulan data, teknik yang dilakukan adalah melalui wawancara semi-terstruktur kepada subjek penelitian yaitu empat orang informan dengan kriteria yang sudah ditentukan. Wawancara cocok digunakan untuk memahami perasaan, persepsi, dan pikiran orang, serta merupakan metode fleksibel yang memungkinkan menanyakan penyelidikan sehingga mendapatkan informasi yang lebih dalam (Daymon \& Holloway, 2011). Wawancara dilakukan dengan mengajukan pertanyaan-pertanyaan terbuka, yang memungkinkan responden memberikan jawaban secara luas. Wawancara yang dilakukan tidak hanya dengan bertemu langsung tatap muka, juga melalui telepon.

Informan dipilih menggunakan teknik purposive sampling. Pemilihan subjek ditentukan berdasarkan kriteria informan yaitu anggota komunitas dari Ria Miranda Loyal Community, aktif terlibat dalam kegiatan komunitas, aktif berinteraksi dengan anggota komunitas melalui Instagram. Asumsi dari pemilihan kriteria ini yaitu untuk mendapatkan data dari informan mengenai konstruksi pengalaman mereka sebagai anggota komunitas dalam berpartisipasi dan memanfaatkan Instagram untuk membangun interaksi antar anggota komunitas.

Data yang dianalisis meliputi data primer dan data sekunder. Sumber data primer terdiri dari data hasil wawancara. Sedangkan sumber data sekunder yaitu data dokumentasi dari berbagai sumber buku, jurnal, arsip, dokumen pribadi, dan 
dokumen resmi. Data yang telah diperoleh melalui wawancara dan kajian kepustakaan kemudian diolah dan diberikan gambaran lengkap pada tahap pembahasan. Teknik analisis data yang digunakan yaitu menganalisis dokumen dan hasil wawancara melalui proses pengolahan data coding dan selanjutnya mendeskripsikan fenomena dengan menggali langsung pengalaman anggota RMLC dan menggambarkan fenomena yang terjadi.

Setelah data diperoleh dari lapangan, tahap selanjutnya yaitu, mengolah data tersebut. Dalam mengolah data peneliti memulai dengan mempersiapkan data dengan membuat verbatim terhadap hasil rekaman wawancara. Proses coding meliputi tiga proses yaitu open coding, axial coding, dan selective coding. Open coding dilakukan dengan memecah data secara terpisah menjadi kategori-kategori dan diberikan kode dan tanda khusus. Selanjutnya, axial coding dilakukan dengan menghubungkan kategori-kategori sehingga akan ditemukan fokus pada kategori atau fenomena khusus yang berkesinambungan atau di antara informan. Kemudian tahap terakhir yaitu selective coding, pada tahap ini peneliti mengintegrasikan kategori-kategori sehingga ditemukan garis merah baik konsep maupun teori.

\section{Hasil Penemuan dan Diskusi}

\section{Komunitas Brand Ria Miranda}

Komunitas merupakan hubungan atau relasi terkait dengan kualitas karakter dalam hubungan antar manusia (Gusfield, 1975). Dalam kehidupan masyarakat modern, komunitas sangat mungkin mengalami perkembangan definisi dimana sejumlah individu yang memiliki kegemaran yang sama dapat membentuk sebuah komunitas. Brand community adalah sekelompok orang yang memiliki minat yang sama pada brand tertentu, menciptakan subkultur di sekitar brand dengan nilai, mitos, hirarki, ritual, dan kosa kata sendiri (Cova \& Pace, 2006). Anggota brand community dapat terlibat dalam beberapa jenis perilaku dalam komunitas, seperti membantu sesama anggota komunitas lain atau berbagi pengalaman dengan mereka (Nambisan \& Baron, 2009).

Titik pusat dari komunitas ini adalah sebuah barang bermerek atau sebuah jasa layanan. Hal ini yang kemudian menjadikan brand community berbeda dengan komunitas lainnya (Muniz \& O’Guinn, 2001). Selanjutnya Porter (2004) menyatakan bahwa brand community adalah para penggemar brand atau produk tertentu yang membentuk semakin banyak kelompok-kelompok online. Komunitas RMLC menjadi tempat berkumpulnya individu-individu yang memiliki ketertarikan yang sama terhadap brand Ria Miranda.

Menurut Muniz dan O'Guinn (2001), brand community merupakan sebuah komunitas spesial yang tidak terikat secara geografis dan berdasarkan hubungan sosial di antara para penggemar sebuah brand. Sama halnya dengan komunitas lainnya, Muniz dan O'Guinn (2001) mengungkapkan brand community memiliki beberapa elemen meliputi:

1. Consciousness of kind

Elemen ini merupakan elemen yang paling penting dimana para anggotanya mendeskripsikan diri mereka sebagai "kami". Anggota komunitas merasakan ikatan yang kuat terhadap brand, dan ikatan yang lebih kuat lagi 
terhadap anggota komunitas yang lain. Pada beberapa level, mereka merasakan apa yang anggota lain rasakan meski belum pernah bertemu.

Dalam hal ini, para anggota komunitas memiliki kesadaran bahwa mereka adalah satu. Artinya mereka memiliki satu perasaan dan tujuan yang sama yaitu sama-sama menyukai produk dari Ria Miranda dan memiliki komitmen untuk mendukung brand tersebut. Para anggota komunitas merasakan keterhubungan antara satu dengan yang lain. Keterhubungan ini bahkan melampaui batas-batas geografis. RMLC tersebar di seluruh Indonesia, namun dapat saling terhubung melalui media sosial Instagram. Meskipun belum pernah saling bertemu sebelumnya, mereka saling terkoneksi dan berbagi kesamaan yang sama. Menurut Anderson (dalam Muniz \& O’Guinn, 2001) komunitas brand dibayangkan sebagai komunitas yang besar. Para anggotanya merasakan bagian dari sebuah komunitas yang besar walaupun tidak pernah bertemu namun dapat dengan mudah membayangkannya.

2. Ritual and tradition

Elemen ini merepresentasikan proses sosial yang vital dimana makna komunitas direproduksi dan ditransmisikan di dalam dan di luar komunitas. Hal ini biasanya berpusat pada pengalaman bersama dalam mengonsumsi brand. Ritual dan tradisi ini bertujuan untuk mempertahankan budaya komunitas.

Ritual dan tradisi dalam komunitas RMLC berkaitan dengan pola konsumsi terhadap brand Ria Miranda. Seperti diungkapkan informan 1 bahwa para anggota komunitas memiliki komitmen untuk mendukung Ria Miranda. Mereka selalu hadir pada acara fashion show atau launching produk Ria Miranda. Hal ini mereka lakukan dalam rangka membentuk sebuah support system bagi brand yang mereka sukai. Dan sebagai kelanjutannya, mereka akan membeli produk dari Ria Miranda setiap meluncurkan koleksi terbaru.

Komunitas merupakan sebuah organisasi yang kecil namun mampu memberikan pengaruh yang besar bagi anggotanya (Ayuningtyas \& Abdullah, 2017). Mengacu pada Manski (1993), salah satu efek keterlibatan dalam komunitas adalah korelasi pengaruh perilaku komunitas pada perilaku individu. Keterlibatan tersebut terlihat pada informan 3 setelah tergabung dalam komunitas Ria Miranda Bekasi, informan 3 menjelaskan bahwa salah satu kebiasaan perilaku dalam komunitas itu adalah secara sengaja mengenakan busana yang sama ketika menghadiri kegiatan komunitas. Kegiatan tersebut memang tidak secara gamblang di tulis dan harus dilaksanakan, namun terkesan seperti sebuah budaya yang harus diikuti yang menimbulkan rasa tidak enak apabila tidak melakukannya. Oleh karena merasa sudah tergabung dalam komunitas, maka informan merasa mau tidak mau harus mengikuti kebiasaan yang ada di dalamnya yang juga berpengaruh langsung pada perilaku informan.

Anggota komunitas juga memiliki kebiasaan mengunggah foto Outfit of The Day (OOTD) dengan brand Ria Miranda. OOTD merupakan sebuah istilah untuk menunjukkan pakaian yang dikenakan pada hari itu. 
Dari pernyataan informan, mereka melakukannya untuk memberikan review mengenai produk Ria Miranda, misalnya dari segi kualitas bahan, motif, dan lainnya. Unggahan foto OOTD di Instagram tersebut juga disertai dengan tagar \#riamirandastyle yang menjadi identitas dari komunitas ini. Ini merupakan praktik dari storytelling atau berbagi cerita mengenai brand. Storytelling memiliki makna yang penting dalam menciptakan dan memelihara komunitas. Cerita yang berdasarkan pengalaman terhadap brand dapat bermakna menghubungkan anggota komunitas dengan brand maupun dengan anggota komunitas yang lain (Muniz \& O'Guinn, 2001).

3. Moral responsibility

Elemen ini merupakan rasa memiliki kewajiban terhadap masyarakat secara keseluruhan dan kepada anggota individu dari komunitas. Rasa tanggung jawab moral ini menghasilkan tindakan kolektif dan berkontribusi pada kohesivitas kelompok. Para anggota komunitas melaksanakan tanggung jawab moral untuk brand melalui diri mereka sendiri untuk mengedukasi orang lain dengan cara yang tepat. Caranya dengan menggunakan brand untuk menarik dan mempertahankan anggota komunitas (Lane, 2018).

Para informan mengatakan bahwa motivasi mereka membagikan foto OOTD dan memakai tagar \#riamirandastyle untuk memberikan referensi style kepada anggota komunitas yang lain. Semisal memadupadankan baju, memberikan gambaran untuk pemakaian produk yang sesuai dengan bentuk dan ukuran badannya. Apa yang mereka lakukan dapat juga dilihat sebagai bentuk bantuan dalam penggunaan produk yang diberikan kepada sesama anggota.

Menurut McMillan dan Chavis (1986), sebuah komunitas yang kuat adalah komunitas yang dapat mempertemukan banyak individu yang memiliki kebutuhan masing-masing, namun di satu sisi ia dapat memenuhi kebutuhan orang lain dan memenuhi kebutuhannya sendiri. Dalam hal ini, kegiatan mendukung produk-produk yang diluncurkan Ria Miranda merupakan kegiatan pemenuhan kebutuhan pada orang lain yaitu pemilik brand Ria Miranda. Sedangkan pada acara fashion show, kajian serta event lainnya, para anggota telah memenuhi kebutuhannya sendiri dalam mendapatkan produk Ria Miranda secara lebih awal dan berinteraksi secara intens dengan teman-teman baru anggota komunitas RMLC pada kegiatankegiatan yang diselenggarakan.

\section{Partisipasi Anggota dalam Interaksi Komunitas}

Dari keterangan informan, didapatkan informasi bagaimana interaksi yang terjadi dalam komunitas RMLC. Interaksi dalam komunitas terbentuk melalui keterlibatan para anggota komunitas dalam kegiatan-kegiatannya. Dalam hal ini, diawali dengan pertemuan dengan komunitas RMLC karena sering mengikuti event yang diselenggarakan oleh Ria Miranda. Informan merasa memiliki kesamaan dengan para anggota komunitas lainnya yang sama-sama menggemari brand Ria Miranda dan memilih gaya berbusana dengan preferensi style Ria Miranda. Karena merasa memiliki nilai yang sama, informan memutuskan untuk bergabung dalam komunitas. Selain itu, informan juga merasakan manfaat dan pengaruh ketika 
Satya Herlina Armananti, Donna Asteria: Partisipasi Anggota dan Pemanfaatan Instagram dalam Interaksi Komunitas Brand Ria Miranda

menjadi anggota komunitas. Manfaat utama yang dirasakan sebagai anggota komunitas adalah mendapat banyak teman baru dan banyaknya kegiatan yang diselenggarakan oleh komunitas. Informan 1 yang merupakan seorang ibu rumah tangga mengaku merasakan manfaat yang besar dengan mengikuti komunitas. Menurut beliau "Kalo aku sih berdampak banget ya, jadi ada kegiatan..soalnya kalo ibu rumah tangga gitu kan bosen juga di rumah terus, kegiatannya kan terbatas" (Informan 1, 2019)

Sependapat dengan informan 1, informan 3 dan 4 juga mengaku mendapatkan banyak teman baru setelah bergabung dengan RMLC. Informan 3 yang baru 4 tahun ini pindah ke Jakarta mengaku tidak memiliki banyak teman di Jakarta. Ia sangat senang mendapat banyak teman di RMLC. Informan 4 yang merupakan pekerja kantoran merasa selain menambah teman, kegiatan-kegiatan komunitas membantu mengalihkan kebosanan dari rutinitas sehari-hari di kantor. Ia kerap bertemu dengan anggota komunitas lain yang sama-sama bekerja di satu kawasan dengan kantornya untuk sekedar makan siang bersama. Menurutnya kehadiran anggota komunitas dapat memberikan suntikan semangat kepadanya.

Sementara itu informan 2 mengaku mendapatkan manfaat dengan bergabung sebagai anggota komunitas melalui kegiatan-kegiatan komunitas yang dirasakan bermanfaat bagi dirinya. Kegiatan-kegiatan tersebut seperti memberi dukungan pada desainer Ria Miranda pada setiap acara fashion show atau peluncuran produk terbaru. Ini juga merupakan bentuk komitmen dari informan sebagai anggota komunitas untuk mendukung brand Ria Miranda. Bagi informan, menjadi bagian dari komunitas sangat menguntungkan karena bisa lebih dekat dengan desainer idolanya. Hal itu terungkap dari perkataan beliau: "kalo misalnya udah pernah ketemu Uni Ria mungkin kayak wahhh ... auranya tuh itu banget gitu” (Informan 1, 2019)

Selain itu, di luar event-event resmi yang diselenggarakan oleh brand, informan juga terlibat dalam kegiatan-kegiatan lain yang diadakan komunitas. Kegiatan tersebut bersifat keagamaan dan sosial seperti kajian, bakti sosial, dan gathering. Menurut informan 1, kegiatan komunitas tidak melulu soal fashion atau kecantikan, ada juga kegiatan-kegiatan yang tujuannya untuk kebaikan. Baginya, kegiatan-kegiatan ini juga sangat bermanfaat sebagai ajang silaturahmi antar anggota komunitas. Oleh karena merasa komunitas ini memiliki satu tujuan yang sama, maka penting untuk melakukan kegiatan seperti berkumpul bersama agar komunitas ini semakin solid.

Selanjutnya, interaksi dalam komunitas juga dilatarbelakangi oleh konsep diri yang dibawa oleh individu sebagai anggota komunitas. Konsep diri tersebut terbentuk melalui motivasi diri individu sebagai anggota komunitas. Informan merasa ingin mengenal anggota komunitas secara lebih dalam, sehingga informan berusaha untuk mengakrabkan diri dengan anggota komunitas yang lain.

"Kayak gathering kan kita pengen silaturahmi nih, jangan cuma kenal karena suka Uni aja, tapi karena kita pengen deep inside, want to know you more" (Informan 1, 2019)

Konsep diri juga terlihat dari perasaan yang dimiliki oleh individu terhadap komunitas. Menurut pengakuan informan 3, dirinya merasa senang ketika bisa sharing dengan anggota lain untuk membicarakan brand Ria Miranda. Hal yang 
sama juga dirasakan informan 4 ketika bisa bertemu langsung dengan anggota komunitas tidak saja anggota komunitas Ria Miranda Jabodetabek, tapi juga anggota komunitas yang berada di luar Jabodetabek.

"Ria Miranda Trunk Show itu momen banget buat ketemu sama temen2 yg dari luar daerah malah. Acaranya walaupun di Jakarta, mereka tuh suka banyak yang dateng. Itu kaya--agak magical deh, tapi iya mereka emang seniat itu untuk acara RMTS tuh orang-orang dari luar daerah bener-bener khusus dateng buat, selain buat nonton shownya, ya buat saling ketemu ini. Yang biasanya cuma ketemu di Instagram, trus ketemuan secara real gitu kan, ngobrol, gitu. Aku juga nggak nyangka, aku pikir tuh kaya ah masa sih dulunya awal-awal, tp pas udah bergabung gini emg ooo iya, justru value yg tidak tergantikannya tuh itu malahan" (Informan 4, 2019)

Interaksi yang terjadi dalam komunitas brand Ria Miranda didukung oleh partisipasi dari para anggotanya. Partisipasi anggota komunitas merupakan satu elemen dalam membangun interaksi di dalam komunitas. Menurut Tsai et al., (2012), community participation terdiri dari dua komponen yaitu member-member interaction dan member-activity involvement. Member-member interaction atau interaksi antar member merujuk sejauh mana anggota komunitas berinteraksi satu sama lain melalui kontak interpersonal yang rutin, komunikasi dua arah, dan saling membantu. Interaksi tersebut merupakan bagian integral dari partisipasi masyarakat merek, karena komunikasi antarpribadi memberikan peluang bagi pengembangan masyarakat melalui penciptaan modal budaya dan difusi ritual dan tradisi (McAlexander et al., 2002; Wasko \& Faraj, 2005). Menurut informasi dari informan 4, misalnya ia sering berkomunikasi dengan anggota komunitas lain yang sama-sama bekerja satu kawasan dengan dirinya. Komunikasi yang lebih intens dengan anggota komunitas yang secara geografis dekat menciptakan sebuah inner circle baginya dan dapat mengembangkan hubungan dalam komunitas.

Sedangkan member-activity involvement merujuk pada sejauh mana anggota berpartisipasi aktif dalam kegiatan komunitas brand, yang memengaruhi evolusi sistem sosial yaitu suatu kolektivitas yang saling berinteraksi yang memiliki pola, aturan, norma, nilai, dan model yang berkelanjutan. (Zimmerman dan Zeitz, 2002). Disini partisipasi anggota komunitas dilakukan melalui keterlibatannya dalam kegiatan-kegiatan komunitas. Ketika memutuskan menjadi bagian dari anggota komunitas, mereka telah berkomitmen untuk ikut mendukung brand dan desainer Ria Miranda. Untuk menunjukkan hal tersebut, para anggota komunitas merasa wajib untuk terlibat dalam kegiatan-kegiatan yang diadakan komunitas baik itu berkaitan dengan event dari brand maupun kegiatan sosial maupun keagamaan. Secara pribadi, mereka merasakan bahwa kegiatan-kegiatan tersebut bermanfaat bagi dirinya dan sebagai wadah silaturahmi dengan anggota komunitas yang lain. Dengan demikian, melalui kegiatan-kegiatan tersebut, anggota komunitas merasakan ikatan yang makin kuat.

\section{Pemanfaatan Instagram sebagai Media untuk Berinteraksi}

Selain melalui kegiatan-kegiatan tatap muka langsung, anggota RMLC juga berinteraksi melalui Instagram dengan anggota lainnya. Media sosial ini membantu 
Satya Herlina Armananti, Donna Asteria: Partisipasi Anggota dan Pemanfaatan Instagram dalam Interaksi Komunitas Brand Ria Miranda

menghubungkan individu sebagai anggota komunitas yang tidak dibatasi secara geografis. Informan mengaku bahwa melalui Instagram mereka bisa terhubung dengan anggota komunitas brand Ria Miranda di seluruh Indonesia. Di samping itu, Instagram juga menjembatani mereka untuk bisa saling mengenal dan bertemu secara langsung pada event-event yang diselenggarakan oleh brand seperti Ria Miranda Trunk Show (RMTS) yang biasanya dihadiri oleh anggota komunitas dari seluruh daerah.

Pada dasarnya, informan menggunakan Instagram untuk meng-update momen dalam hidup dan untuk menyimpan memori terkait momen dalam hidupnya. Sehingga dalam penggunaannya, informan hanya mengunggah konten ketika ada momen yang sedang terjadi.

"Buat update-update kehidupan sihh, kayak lifetime album, pernah ngapain aja, kemana aja, sebagai pengganti album foto fisik kali yaa, karena udah gak cetak-cetak foto lagi kan semua udah di keep di internet, katanya kan internet never dies, buat memperlihatkan momen apa yang paling menarik dalam hidup, kayak Instagram tuh ibarat milestone kehidupan, setiap step kehidupan pasti di update secara sadar atau gak sadar" (Informan 2, 2019)

Terkait dengan konten yang diposting, mayoritas informan kerap mengunggah foto OOTD (Outfit of the Day). Hal ini tidak lepas dari gaya hidup mereka yang memang menyukai hijab dan modest fashion sehingga ingin menunjukkan gaya berpakaian mereka di dunia maya. Informan 1 mengatakan ia senang membagikan foto OOTD khususnya dengan memakai produk Ria Miranda untuk memperlihatkan eksistensinya sebagai anggota komunitas. Berbeda halnya dengan informan 3 yang memang sengaja mengunggah foto OOTD untuk mengikuti giveaway, semacam kuis yang diadakan oleh brand fashion dengan mengajak pengikutnya di Instagram mengirimkan foto OOTD mengenakan brand tersebut.

Instagram juga digunakan sebagai media untuk berkomunikasi dengan anggota komunitas. Melalui Instagram, informan saling menyapa anggota komunitas tidak hanya komunitas RMLC Jabodetabek saja, tapi juga komunitas Ria Miranda yang berada di luar Jabodetabek. Seperti diungkapkan Informan 1: “..kayak kenal-kenal RMLC dari kota lain kan dari Instagram itu. Kayak bertukar Instagram."

Informan memanfaatkan fitur yang ada di Instagram seperti memberikan likes dan komentar. Hal ini diutarakan oleh informan 3 bahwa untuk mengakrabkan diri dengan anggota komunitas yang lain, mereka saling memberikan pujian pada foto OOTD yang diunggah oleh anggota komunitas.

Ciri khas Instagram yang dapat menyertakan tagar pada tiap unggahan foto dimanfaatkan pula anggota komunitas. Informan sering menggunakan tagar \#riamirandastyle ketika mengunggah foto OOTD-nya maupun foto bersama anggota komunitas RMLC. Mayoritas informan mengatakan bahwa tujuan utama penggunaan tagar tersebut adalah untuk memberikan referensi kepada orang lain tentang gaya berpakaian dengan produk Ria Miranda. Selain itu juga untuk memberikan ulasan mengenai produk Ria Miranda. 
"Aku lebih ke sharing sih. Karena kadang banyak juga orang yang mau beli produk A gitu kan, kadang suka banyak yang nyari, termasuk aku juga suka gitu sih, nyari referensi dulu nih produk ini, kalo pake hashtag kan enak ya nyarinya, gampang gitu loh, langsung ketemu. Jadi keliatan kan, oh kalo dipake yang ukuran badan segini jadinya jatohnya kayak gini di badan. Kayak gitu sih lebih jadi referensi.. Referensi pemakaian ya jatohnya" (Informan 4, 2019)

Selain itu, informan 1 dan 4 mengakui mereka juga menggunakan tagar tersebut untuk mencari rekomendasi ketika ingin membeli produk Ria Miranda. Sementara informan 3 mengungkapkan jika dirinya menggunakan tagar tersebut agar dapat dilihat oleh anggota komunitas yang lain. Lebih jauh, informan 2 menambahkan dirinya memaknai tagar \#riamirandastyle bertujuan untuk memperkenalkan produk Ria Miranda dan memperlihatkan kualitasnya sebagai brand lokal. Seperti yang dinyatakan oleh informan mengenai kebanggaannya terhadap desainer brand lokal.

Pemanfaatan Instagram oleh anggota komunitas membantu memenuhi kebutuhan mereka untuk berbagi informasi mengenai produk dan membantu memberikan referensi terhadap penggunaan produk. Melalui Instagram, anggota komunitas dapat mengunggah foto gaya berpakaian mereka dan memperlihatkannya ke anggota komunitas yang lain. Selain itu penggunaan hastag juga mereka pergunakan untuk menunjukkan identitas komunitas kepada orangorang di luar komunitas.

Berkaitan dengan interaksi antara individu sebagai anggota komunitas dengan individu yang lain, mereka juga melakukannya melalui Instagram dengan saling memberikan likes dan comment. Seperti yang disebutkan oleh Chan dan Ma (2013) bahwa saat orang berbagi foto, pengetahuan, dan perasaan pribadi, dan menerima balasan, komentar, dan umpan balik dimana media sosial sekarang dapat digunakan untuk membangun komunitas. Dengan cara berinteraksi tersebut, hubungan yang dibangun antar anggota menjadi lebih erat.

Menurut Kaplan dan Haenlein (2010) komunitas brand di media sosial memiliki tiga karakteristik. Pertama, mereka memungkinkan kehadiran sosial dalam bentuk kontak akustik, visual, dan fisik, yang muncul di antara mitra komunikasi. Kedua, menurut teori media richness, tujuan segala komunikasi adalah menghindari ketidakpastian dan mengurangi ambiguitas. Beberapa media lebih efektif daripada yang lain dalam menyelesaikan masalah ini, dan komunitas brand di media sosial sangat cocok untuk tujuan ini karena banyaknya informasi yang dikirim pada waktu tertentu. Ketiga, komunitas brand di media sosial juga sangat terkait dengan konsep presentasi diri, yang berarti bahwa individu berkeinginan untuk mengendalikan kesan bahwa orang lain membentuk mereka melalui semua jenis interaksi sosial. Pengungkapan diri juga merupakan bagian penting dari pengembangan hubungan, yang sering terjadi di media sosial dan terutama di situs jejaring sosial seperti Instagram. 


\section{Simpulan}

Hasil temuan dan diskusi menyimpulkan bahwa interaksi dalam komunitas terjadi melalui partisipasi anggota komunitas yang meliputi member-member interactions dan member-activity involvement. Hal ini mencakup komunikasi yang dilakukan secara interpersonal antar anggota komunitas satu dengan yang lain, serta keterlibatan anggota komunitas dalam kegiatan-kegiatan komunitas. Partisipasi dari anggota mendukung terbangunnya interaksi dalam komunitas sehingga menumbuhkan ikatan yang lebih kuat antar anggota dalam komunitas.

Untuk memudahkan komunikasi dalam membangun interaksi dalam komunitas, anggota komunitas memanfaatkan Instagram sebagai media sosial untuk memfasilitasi kebutuhan mereka dalam berbagi informasi mengenai produk dan referensi penggunaan produk. Selain itu pemanfaatan media sosial memudahkan mereka berkomunikasi tanpa adanya batasan geografis. Fitur-fitur yang ada di Instagram seperti likes dan comment mampu menghubungkan anggota komunitas secara lebih akrab. Unggahan foto OOTD dan penggunaan hastag juga membantu untuk memberikan identitas sosial bagi anggota komunitas.

\section{Ucapan Terima Kasih}

Penelitian ini dapat terlaksana atas dukungan dari berbagai pihak yang telah banyak membantu, khususnya para narasumber anggota komunitas RMLC, Dr. Donna Asteria atas masukan dan bimbingannya, serta teman-teman Program Pascasarjana Ilmu Komunikasi Universitas Indonesia Angkatan 2018.

\section{Daftar Pustaka}

Ayuningtyas, F., \& Abdullah, A.Z. (2017). Kognisi Sosial Melalui Situs Jejaring Youtube Pada Komunitas Online (Studi Kasus pada Komunitas Online LinkPictureID). Jurnal Komunikasi, 9(2): 137-150. https://journal.untar.ac.id/index.php/komunikasi/article/view/1076

Beirão, G., \& Cabral, J.S. (2007). Understanding attitudes towards public transport and private car: A qualitative study. Transport policy, 14(6): 478-489.

Chan, W.W.L., \& Ma, W.W.K. (2013). Exploring the Influence of Social Ties and Perceived Privacy on Trust in a Social Media Learning Community. In, Hybrid Learning and Continuing Education, 134-144. Springer Berlin Heidelberg.

Cova, B., \& Pace, S. (2006). Brand community of convenience products: new forms of customers empowerment - the case of my Nutella community. European Journal of Marketing, 40(9-10): 1087-105.

Daymon, C., \& Holloway, I. (2011). "Qualitative Research Methods in Public Relations and Marketing Communication". [e-book]. New York (US): Routledge.

DePaul University. (2007). DePaul marketing professor's study that coined the phrase "brand community" among the most cited research worldwide. 
Chicago (US): Press release. Available at: http://wdat.is.depaul.edu/newsroom/year_2007/1609.html

Fraser, B.J., Tobin, K.G., \& McRobbie, C.J. (2012). Constructivism: Value added. Second International Handbook of Science Education, (June), 1-1564. https://doi.org/10.1007/978-1-4020-9041-7

Gusfield, J.R. (1975). Community: A critical response. New York: Harper \& Row.

Kaplan, A.M. \& Haenlein, M. (2010). Users of the world, unite! The challenges and opportunities of social media. Business Horizons, 53(1): 59-68.

Lane, J. (2018). Rethinking the brand-community relationship: Wearing a biggie in Harlem. Journal of Consumer Culture, 0(0): 1-17. https://doi.org/10.1177/1469540518773823

Manski, C.F. (1993). Identification of endogeneous social effects: the reflection problem. Review of Economic Studies, 60(3): 531-542.

McAlexander, J.H, Schouten, J.W, \& Koenig, H.F. (2002). Building brand community. J Mark, 66(1): 38-54.

McMillan, D.W., \& Chavis, D.M. (1986). Sense of community: A definition and theory. Journal of community psychology, 14(1), 6-23.

Muniz, A.M., \& O'Guinn, T.C. (2001). Brand community. Journal of Consumer Research, 27(4): 412-432. https://doi.org/10.1086/319618

Nambisan, S., \& Baron, R.A. (2009). Virtual customer environments: texting a model of voluntary participation in value co-creation activities. Journal of Product Innovation Management, 26: 388-406.

Patton, M.Q. (1987). How to Use Qualitative Methods in Evaluation. California (US): SAGE Publications.

Porter, C.E. (2004). A typology of virtual communities: a multi-disciplinary foundation for future research. Journal of Computer-mediated Communication, $\quad 10(1): \quad 00 . \quad$ https://doi.org/10.1111/j.10836101.2004.tb00228.x

Tsai, H.T., Huang, H.C., \& Chiu, Y.L. (2012). Brand community participation in Taiwan: Examining roles of individual, group, and relationship-level antecedents. Journal of Business Research, 65(5): 676-684.

Wasko, M.M, \& Faraj, S. (2005). Why should I share? Examining social capital and knowledge contribution in electronic networks of practice. MIS $Q$, 29(1): 35-57.

Zimmerman, M.A. \& Zeitz, G.J. (2002). Beyond Survival: Achieving New Venture Growth by Building Legitimacy. Academy of Management Review, 27: 414431. 